\title{
The 2015 recipient of the Brady Medal: Dr Martin A. Buzas
}

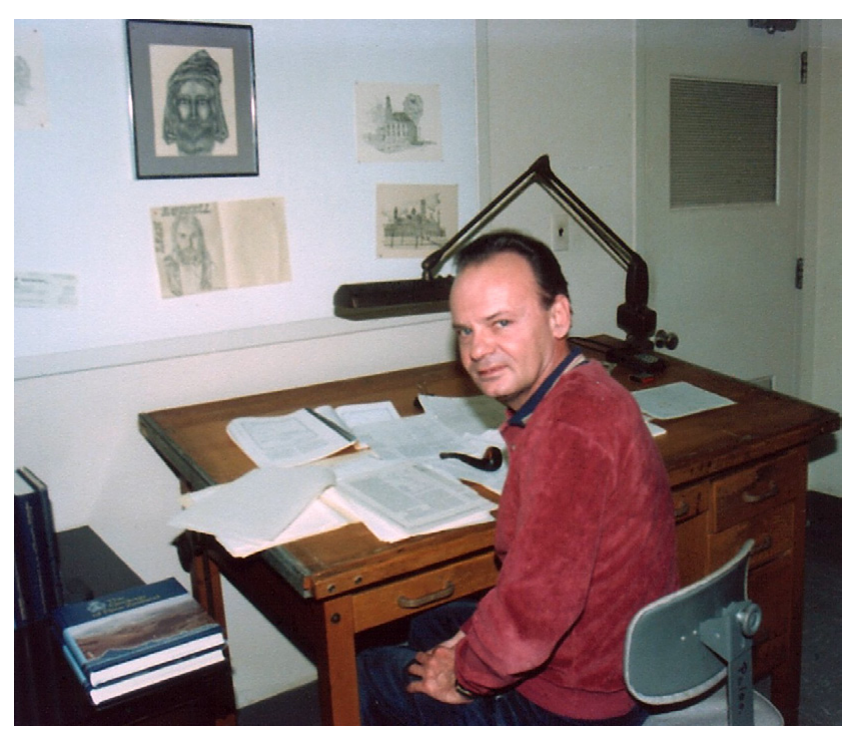

Marty Buzas is an outstanding scientist who has devoted his lifetime's research to furthering our knowledge of statistics and its application to understanding the ecology of benthic foraminifera.

Marty was born in 1934 in Bridgeport, Connecticut, USA to Hungarian parents. He has Geology degrees from the universities of Connecticut (BA 1958), Brown (MSc 1960) and Yale (PhD 1963). The influence of the statistician Hilary Seal and the ecologist G. Evelyn Hutchinson profoundly affected his career. On the completion of his $\mathrm{PhD}$ he was recruited by the Smithsonian Institution, Washington, DC, because of his palaeontological and quantitative skills. He has continued to work there and still does research there even in retirement and has now completed 57 years of excellent work.

Throughout this long career Marty has concerned himself with the spatial and temporal distribution of foraminifera. This has been done on scales of millimetres to kilometres and time periods of days to millions of years. Statistical methods have been the key to establishing ecological relationships. For younger readers it must be pointed out that computers were not available to researchers until the mid-late 1960s and the early versions were totally unfriendly to users. Prior to this, all calculations had to be done in the mind or on primitive mechanical calculators. Nevertheless, from his first publication (on the ecology of Long Island Sound, USA, in 1965) statistical analytical techniques were applied to the interpretation of numerical data to reveal similarities and differences between assemblages. A great variety of mathematical methods has been applied and developed over the years of his research. He has been a major advocate of using diversity indices to show environmental trends in assemblages. He has pioneered the use of SHE analysis ( $\mathrm{S}$ number of species, $\mathrm{H}$ information function, E evenness) to determine whether diversity follows a log-series, log-normal or broken-stick pattern and to recognize biofacies. He has also used a wide range of multivariate methods to relate assemblages to environmental variables. All this groundwork led to the publication of Surveying Natural Populations, jointly with LeeAnn Hayek, a fellow researcher at the Smithsonian (1997, 2nd edn
2010). This book deals with basic statistical methods, planning sampling in the field, patterns of abundance, and all aspects of biodiversity. The book is relevant to all ecological studies, not just those on benthic foraminifera. Indeed, the case studies include tropical rainforest. This is a classic book that is essential reading for those interested in ecology.

Marty was one of the first to recognize that some foraminifera are infaunal in the sediment. Importantly, he has demonstrated this is controlled by local geochemical conditions in the sediment rather than depth per se. This has implications for the selection of taxa for stable isotope studies. Through experiment he has demonstrated that food (amount and kind) is important in controlling species densities. Likewise, his field experiments have also demonstrated the role of predators in controlling foraminiferal densities. These are examples where he has led the field in contributions to small-scale aspects of ecology.

Time-series studies have been carried out over periods of months and several years by a number of contributors. Marty has brought statistical rigour to such studies, showing that it is essential to have replicates (ideally at least four from each sampling site and sampling period) and to use appropriate techniques to evaluate the long-term changes. For more than 30 years his work has focused on the Indian River Lagoon, Florida, USA. He has revealed the extent of variability in species distributions and abundance on scales of millimetres to tens of metres and on timescales of months to years. In 2002 he introduced the concept of 'pulsating patches' to describe these changes. In 2015 he published a synthesis of all available data on time-series and pulsating patches in a paper that is clearly a classic. Indeed, he gave an excellent presentation on this theme immediately prior to receiving the Brady Medal.

In the 1980s, in collaboration with Steve Culver and others, he made a synthesis of distributional data on modern benthic foraminifera in the seas around North America in a series of publications. This led to an understanding of the biogeography of different faunal provinces, their diversity, dispersal of species and the concept of the species pool (the sum total of species living in a major environment) as the source for the species in each province. This approach was then applied to the Cenozoic fossil record of the Atlantic seaboard of the USA. They concluded that common and rare species have a duration of approximately $21 \mathrm{myr}$, that there are no centres of evolution and that dispersal of new species is rapid based on the widespread occurrence of rare taxa.

Marty has also made significant contributions to foraminiferal taxonomy, particularly of Elphidium and Haynesina, again using statistical techniques. The genus Buzasina Loeblich \& Tappan, 1985, was named in his honour.

Marty has also served the wider science community in a number of ways. He has been a guiding influence for more than $30 \mathrm{PhD}$ students and Adjunct Professor at several US universities. He was Director of the Department of Paleobiology at the Smithsonian Institution for several years. He has been a Director of the Cushman Foundation for Foraminiferal Research for several decades and served twice as President as well as serving on the boards of numerous other scientific societies. His daughter, Pamela Buzas Stephens, has followed in his footsteps as a foraminiferalogist and a Director of the Cushman Foundation. 
Marty's contributions to research and serving science have been recognized by many previous awards, including the Joseph A. Cushman Award for outstanding achievement in foraminiferal research and the Paleontological Society Medal. The Micropalaeontological Society recognizes this outstanding record, and its still innovative continuation into Marty's 80s, by the award of the Brady Medal.

\section{Selected bibliography}

Buzas, M.A. 1965. The distribution and abundance of foraminifera in Long Island Sound. Smithsonian Miscellaneous Collections, 149, 1-89.

Buzas, M.A. 1978. Foraminifera as prey for benthic deposit feeders: Results of predator exclusion experiments. Journal of Marine Science, 36, 617-625.

Buzas, M.A. \& Culver, S.J. 1980. Foraminifera: distribution of provinces in the western North Atlantic. Science, 209, 687-689.

Buzas, M.A. \& Culver, S.J. 1994. Species pool and dynamics of marine paleocommunities. Science, 264, 1439-1441.

Buzas, M.A. \& Hayek, L.E.C. 1998. SHE analysis for biofacies identification. Journal of Foraminiferal Research, 28, 233-239.

Buzas, M.A., Culver, S.J. \& Isham, L.B. 1985. A comparison of fourteen elphidiid (Foraminiferida) taxa. Journal of Paleontology, 59, 1075-1090.

Buzas, M.A., Hayek, L.C., Reed, S.A. \& Jett, J.A. 2002. Foraminiferal densities over five years in the Indian River lagoon, Florida: A model of pulsating patches. Journal of Foraminiferal Research, 32, 68-93.

Buzas, M.A., Hayek, L.C., Jett, J.A. \& Reed, S.A. 2015. Pulsating patches. History of analysis of spatial, seasonal, and yearly distribution of living benthic foraminifera. Smithsonian Contributions to Paleobiology, 97, $1-91$.

Hayek, L.A.C. \& Buzas, M.A. 1997. Surveying Natural Populations. Columbia University Press, New York.

Hayek, L.A.C. \& Buzas, M.A. 2010. Surveying Natural Populations. Quantitative Tools for Assessing Biodiversity. Columbia University Press, New York.

Loeblich, A.R., Jr, \& Tappan, H. 1985. Some new and redefined genera and families of agglutinated foraminifera. 1. Journal of Foraminiferal Research $15,91-104$.

John W. Murray

Ocean and Earth Science,

University of Southampton,

National Oceanography

Centre, European Way,

Southampton SO14 3ZH, UK
Stephen J. Culver

Department of Geological Sciences, East Carolina University, Greenville, North Carolina 27858, USA 


\section{BiotecMicroslides}

Little Lower Ease

Cuckfield Road

ANSTY

West Sussex RH17 5AL

England

Tel/Fax: +44 (0)1444 452282

Email: sales@biotecmicroslides.co.uk

Web: www.biotecmicroslides.co.uk

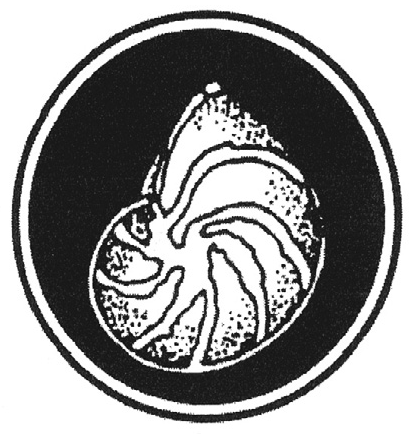

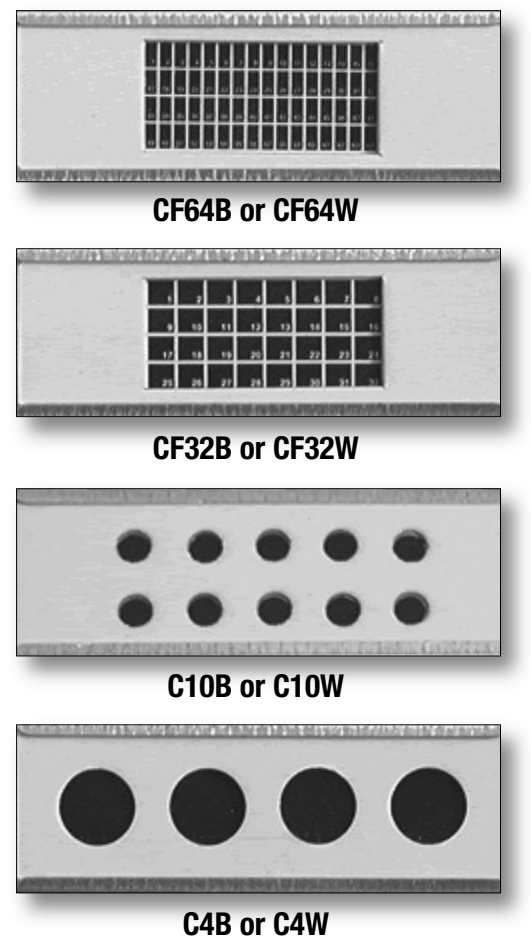
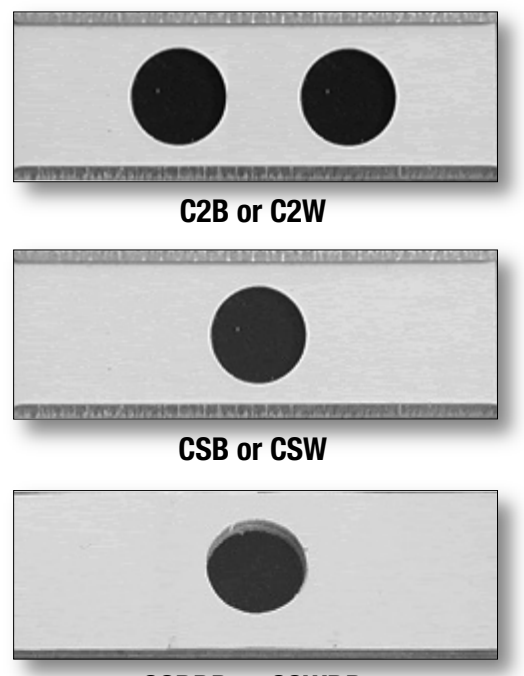

CSBDD or CSWDD
BiotecMicroslides has been manufacturing slides for the storage of microfossils and small zoological and botanical specimens since 1974 .

Slides, with either black or white cell backgrounds are available in cardboard with aluminium holder and glass coverslide. Also available to order are double-depth single-cell slides with paper tops and either acetate or glass coverslip.

Slide dimensions 3" x 1" (76mm x 27mm)

- Pine Storage Cabinets (28 drawers) with or without glazed door

- Picking trays $3 \frac{3 / 4}{4} \times 3^{1 / 4}$ (97mm x 84mm)

- 00 Picking brushes with sable or synthetic bristles 